estimated fairly accurately over a term of years. The average cost per scientist was also fairly steady, and a rate of growth of 10 per cent in investment was indicated. From these investigations, assumptions are made which lead to projections of expenditure on scientific and technological research, by the Central Government, and by the State Governments; of expenditure by the Central and State Governments on research in universities; and of expenditure by organized industry on research. For university research, figures of Rs. 46.0 million and $R s$. 116.8 million, respectively, are suggested for the first and final years of the Plan, or Rs. 388 million in the university sector $(4.4$ per cent of the total investment in scientific research) during the quinquennium. Expenditure by organized industry is put at $\mathrm{Rs}$. 193.4 million in 1966-67, rising to Rs. 343.1 million in 1970-71, or an investment of Rs. 1,317 million during the period, 14.8 per cent of the total investment on research.

\section{Art and Design}

There is a widespread and growing interest in design among manufacturers and the general public, and in recent years the majority of students who have successfully completed a period of training at one of the recognized art schools have been able to find employment in some sphere of design. There is also a steady demand for art teachers. In most branches of art other than design, however, the openings occurring each year are to be reckoned in tens, not hundreds, and it takes time for even the most talented to establish themselves as free-lance artists. This information is given in a revised illustrated edition of Art and Design (Central Youth Employment Executive. Choice of Careers, No. 103. Pp. 55. London: H.M. Stationery Office, 1964. 2s. net). The booklet groups occupations in design under the following headings : the graphic arts ; fashion design ; package design; product design; design for woven textiles and printed materials; design for entertainment (set design, animated films and television). Particulars of educational qualifications for designers, professional training, examinations, cost of training, openings, and some indication of salaries, are also given.

\section{The National Museums of Southern Rhodesia}

THe major task during 1963 for the National Museums of Southern Rhodesia was the installation of interior fittings and displays in the three new Museums (Report of the Trustees and Directors of the National Museums of Southern Rhodesia for the year ended December 31, 1963. Pp. 32. Salisbury: National Museums of Southern Rhodesia, 1964). In the initial planning of this work adequate display teams were envisaged. As so often happens in the museum field, in the event this was not forthcoming, though at the end of the year it was arranged that the opening of the three Museums would be in 1964 . The Councils of the City of Bulawayo, the City of Salisbury and the Town Council of Umtali all made provision for the sites of the new buildings and in many ways have played a major part in making these developments possible. The three Councils continue to provide maintenance grants. In spite of their preoccupation with the moves to the new buildings the staff have been able to continue research work, as is testified by a series of publications. It is also pleasing to note that Captain E. F. Boultbee continues as honorary keeper of arms and antiquities at the Umtali Museum.

\section{Natural History in the U.S.S.R.}

THE woekly journal of the Russian book trade, Novye Knigi (No. 51; 1964), announces the forthcoming publication of a series of pocket-sized popular handbooks on the mammals, birds, roptiles, fishes, insects, trees and shrubs, grasses and flowering plants, and rocks and minerals of the U.S.S.R. The works, in Russian, are intended for the use of older school-children, amateur naturalists and tourists, and will be extensively illustrated in colour. The edition is 50,000 copies of each, length 20 printers' sheets, price 1r. 75k. (about $£ 1$ ). The first book of the series, on mammals, will be published in 1965 and the others over the next three years.

\section{International Subject Bibliographies}

Maxwell's International Subject Bibliographies No. 1 deals with electronics, including control engineering, covering the period 1960-63, but excluding medical and biological electronics and books on computers published in 1963-64, for which a special bibliography (No. 29) is available. Special Subject Bibliography No. 6 covers orthopaedics, including rehabilitation of the pbysically handicapped, but excluding myology, physical education in general and rehabilitation of the blind and deaf. This second edition covers the period 1961-63. Special Subject Bibliography No. 10 covers electrochemistry, including polarography, 1953-May 1964; No. 19 covers reinforced plastics, including polyester resins, plasticizers and glass film products, January 1960-June 1964; and No. 28 deals with machine tools and machine tool design, excluding drilling, polishing, cutting, grinding and pressing tools, which are covered by No. 9. This second edition refers to the period 1961-May 1964 (Oxford: Robert Maxwell and Co., Ltd.; Long Island City, N.Y.: Maxwell Scientific International, Inc., 1964).

\section{Wheat Research in Australia}

THE annual report of the Wheat Research Unit of the Commonwealth Scientific and Industrial Research Organization for 1963 -64 is a summary of work in progress, illustrating very clearly the possibilities of applying modern techniques to the investigation of the complex mixture of protein and carbohydrate that is the basis of bread dough (Pp. 15. Ryde, N.S.W.: Commonwealth Scientific and Industrial Research Organization, 1964). In fact, almost the entire effort of the laboratory is being devoted to the separation of homogeneous fractions of the complex in amounts sufficient for baking tests. The main research effort is concerned with the fractionation of the proteins comprising the gluten complex. A many-sided attack on this difficult problem is being made, using the techniques of column chromatography, starch-gel electrophoresis and gel-filtration. A particularly interesting aspect is the examination of the effect of ionic strength on the behaviour of gluten proteins during gel filtration on 'Sephadex'. This should ultimately provide a better understanding of the role of gluten proteins in relation to the physical properties of dough. Preparations of flour gum have been shown to be effective in increasing the volume of starch-gluten loaves, but pentosans from other sources can produce similar effects, the most effective being those with the main chain carrying large substituent groups. However, one surprising fact to be reported is the inhibition of yeast fermentation by the presence of 3 p.p.m. of chitosan (partially deacetylated chitin). Pentosan degradation investigations using "snail juice enzymes" have shown that, while loss of baking quality can result from the action of pentosanases, the neutralizing or improving effect of oxidizing agents such as potassium bromate cannot be explained by their ability to promote gelling of pentosans.

\section{Soils of the Middle Teign Valley District of Devon}

THe Soil Survey of Great Britain normally prepares memoirs to accompany soil maps; it has now started to publish Bulletins dealing with investigations of special interest. The first to be issued is concerned with a district of eight parishes around Dunsford, of total area 40 square miles, of which the southern half comprises the Teign Valley between Groat Haldon and Dartmoor (Bulletin No. 1: Soils of the Middle Teign Valley District of Devon. By B. Clayden. Pp. vii $+111+$ map. Harpenden: Rothamsted Experimental Station, 1964. 25s. net). 